Komatsu M, Minoda K (1983) A recognizable pattern of the midface of retinoblastoma patients with interstitial deletion of 13q. Hum Genet 64:160-162

Nichols W, Miller R, Sobel M, Hoffman E, Sparkes RS, Mohandas T, Veomett IC, et al (1980) Further observation on a $13 q X p$ translocation associated with retinoblastoma. Am J Ophthalmol 89:621-627

Ohtani-Fujita N, Fujita R, Aoike A, Osifchin NE, Robbins PD, Sakai T (1993) CpG methylation inactivates the promoter activity of the human tumor-suppressor gene. Oncogene 8: 1063-1067

Petit P, Fryns JP (1979) Interstitial deletion of 13q associated with retinoblastoma and congenital malformations. Ann Genet 22:106-107

Ponzio G, Savin E, Cattaneo G, Ghiotti MP, Marra A, Zuffardi O, Danesio C (1987) Translocation X;13 in a patient with retinoblastoma. J Med Genet 24:431-434

Razin A, Shemer R (1995) DNA methylation in early development. Hum Mol Genet 4:1751-1755

Sakai T, Toguchida J, Ohtani N, Yandell DW, Rapaport JM, Dryja TP (1991) Allele-specific hypermethylation of the retinoblastoma tumor-suppressor gene. Am J Hum Genet 48: 880-888

Turleau C, de Grouchy J, Chavin-Coli NF, Junam C, Senger J, Haye C (1985) Cytogenetic forms of retinoblastoma: their incidence in a survey of 66 patients. Cancer Genet Cytogenet $16: 321$

Willard HF (1995) The sex chromosomes and X inactivation. In: Scriver CR, Beaudet AL, Sly WS, Valle D (eds) The metabolic and molecular bases of inherited disease. McGrawHill, New York, pp 717-737

Address for correspondence and reprints: Dr. Carrie H. Jones, Gottlieb Memorial Hospital, 1140 Westgate, Oak Park, IL 60301.

*Present affiliation: Gottlieb Memorial Hospital, Oak Park, IL.

(C) 1997 by The American Society of Human Genetics. All rights reserved. 0002-9297/97/6006-0040\$02.00

Am. J. Hum. Genet. 60:1562-1563, 1997

\section{Meiotic Drive at the Myotonic Dystrophy and the Cone-Rod Dystrophy Loci on Chromosome 19q13.3}

To the Editor:

The apparently conflicting observations of a high newmutation rate at the myotonic dystrophy (DM) locus on chromosome 19q13.3 and of a founder effect for DM chromosomes led researchers to invoke the influence of meiotic drive at this locus. Two studies (Carey et al. 1994; Gennarelli et al. 1994) suggested such an effect in male meioses, whereas one study (Shaw et al. 1995) found evidence for segregation distortion in female meioses. In the October 1996 issue of the Journal, Leeflang et al. demonstrated convincing evidence that, if such an effect exists in male meioses, it must operate postejaculation, presumably influencing sperm motility or sperm survival. In so doing, the authors also reviewed the literature both supporting and opposing the influence of the action of meiotic drive at the DM locus. However, they appear to have missed a report from our laboratory (Evans et al. 1994) of a similar observation for dominant cone-rod dystrophy (CORD2), a form of retinal degeneration that also maps to chromosome $19 \mathrm{q}$. The data from the study of the CORD2 locus suggest segregation distortion in female meioses. The most recent locus refinement for CORD2 (Bellingham et al., in press) places it in an interval $0.8-2.4 \mathrm{Mb}$ distal to the DM locus, on the metric FISH map of Gordon et al. (1995). Is it not possible that the close proximity of these two loci, both of which apparently have such an unusual pattern of inheritance, is more than a coincidence?

There appear to be five hypotheses to explain this observation.

1. It is possible that this is indeed no more than a coincidence. Several reports of anomalous segregation for other human conditions exist in the literature, although most of these were tentative and remain unconfirmed. These conditions include split-hand/split-foot malformation (Stevenson and Jennings 1960), retinoblastoma (Munier et al. 1992), aniridia (Shaw et al. 1960), Alport syndrome (Shaw and Glover 1961), and postaxial polysyndactyly (Orioli 1995). Evidence for segregation distortion of alleles for several blood-group markers also has been observed (Palaniappan et al. 1996). Nevertheless, meiotic drive in humans remains a relatively rare phenomenon, so this hypothesis seems unlikely.

2. It is not unreasonable to speculate that these diseases may be allelic, since DM patients do have some visual symptoms (Burian and Burns 1967). However, these symptoms are clinically very different from the symptoms of CORD2. In addition, in the CORD2linked family, there is a crossover between the phenotype and the DM expansion, which also is seen with two other markers that are distal to DM and proximal to CORD2 (data not shown). This hypothesis therefore is excluded.

3. A third hypothesis would suppose that gamete selection at both loci operates on the alleles of the DM locus. If the mutation in the CORD2 family arose on a chromosome containing a DM allele of 19 repeats, which is one of the founder chromosomes first postulated by Imbert et al. (1993), then patients with CORD2 would carry a predisposition to DM but not the disease itself. CORD2 then would be selected in gametes not because of any allele at this locus but because it was in linkage disequilibrium with the DM predisposing allele. However, the linked DM allele in the CORD2 family is in fact the smallest, most common allele-that is, the 
five-repeat allele (data not shown) - reported by Brook et al. (1992). Therefore, this hypothesis also appears to be excluded.

4. When the converse of the third hypothesis is considered, a gamete-selection effect for the CORD2 gene, with the DM locus in linkage disequilibrium, could be possible. Sperm-motility effects (actually defects) have been implicated in some inherited eye diseases (Arden and Fox 1976), although this line of research has "gone cold" more recently. Also, Small (1993) observed evidence for segregation distortion in macular dystrophy, another disease of the central retina, which is linked to chromosome 6 . In this scenario, the visual symptoms in DM patients may be interpreted as deriving from a less severe allele at the CORD2 locus, which is in linkage disequilibrium with DM and is subject to meiotic drive. This hypothesis could be tested by the determination of whether the DM-chromosome founder-effect region described by Imbert et al. (1993) extends as far as the CORD2 locus.

5. A fifth hypothesis would invoke the existence of another gene, in the vicinity of the DM and CORD2 loci, with an allele or alleles that are in linkage disequilibrium with both the DM and CORD2 loci and that confer an advantage in gamete selection. Although interesting, this theory unfortunately is untestable at present.

As Leeflang et al. (1996) point out, the very existence of meiotic drive in band 19q13.3 remains controversial. Further testing of DM founder-effect chromosomes may help to distinguish between the fourth and fifth hypotheses described above. Nevertheless, whatever the outcome of that analysis, the observation of meiotic drive at two such physically close loci surely must remain a significant consideration in this debate.

CHRIS F. INGLEHEARN AND CHERYL Y. GREgORY Department of Molecular Genetics

Institute of Ophthalmology

University College London

London

\section{Acknowledgments}

We gratefully acknowledge the Wellcome Trust (grants $035535 / 92$ and $043825 / 95)$ for funding.

\section{References}

Arden GB, Fox B (1976) Increased incidence of abnormal nasal cilia in patients with retinitis pigmentosa. Nature 279:534536

Bellingham J, Wijesuriya SD, Evans K, Fryer A, Lennon G, Gregory CY. Genetic and physical localization of the gene causing cone-rod dystrophy (CORD2). In: LaVail MM, An- derson RE, Hollyfield JG (eds) Degenerative diseases of the retina. Plenum Press, New York (in press)

Brook JD, McCurrach ME, Harley HG, Buckler AJ, Church D, Aburatani H, Hunter K, et al (1992) Molecular basis of myotonic dystrophy: expansion of a trinucleotide (CTG) repeat at the $3^{\prime}$ end of a transcript encoding a protein kinase family member. Cell 68:799-808

Burian HM, Burns CA (1967) Ocular changes in myotonic dystrophy. Am J Ophthalmol 63:22-34

Carey N, Johnson K, Nokelainen P, Savontaus M-L, Juvonen V, Anvret M, Grandell U, et al (1994) Meiotic drive at the myotonic dystrophy locus? Nat Genet 6:117-118

Evans K, Fryer A, Inglehearn CF, Duvall-Young J, Whittaker JL, Gregory CY, Butler R, et al (1994) Genetic linkage of cone-rod dystrophy to chromosome $19 \mathrm{q}$ and evidence for segregation distortion. Nat Genet 6:210-213

Gennarelli M, Dallapiccola B, Baiget M, Martorell L, Novelli G (1994) Meiotic drive at the myotonic dystrophy locus. J Med Genet 31:980

Gordon LA, Bergmann A, Christensen M, Danganan L, Lee DA, Ashworth LK, Nelson D, et al (1995) A 30-Mb metric fluorescence in situ hybridization map of human chromosome 19 q. Genomics 30:187-192

Imbert G, Kretz C, Johnson K, Mandell J-L (1993) Origin of the expansion mutation in myotonic dystrophy. Nat Genet 4:72-76

Leeflang EP, McPeek MS, Arnheim N (1996) Analysis of meiotic segregation, using single-sperm typing: meiotic drive at the myotonic dystrophy locus. Am J Hum Genet 59:896904

Munier F, Spence MA, Pescia G, Balmer A, Gailloud C, Thonney $F$, van Melle $G$, et al (1992) Paternal selection favoring mutant alleles of the retinoblastoma susceptibility gene. Hum Genet 89:508-512

Orioli IM (1995) Segregation distortion in the offspring of Afro-American fathers with postaxial polydactyly. Am J Hum Genet 56:1207-1211

Palaniappan SN, Martin KA, Marsh JL, Sparkes RS, Conneally PM, Spence MA (1996) Segregation distortion in humans. Am J Hum Genet Suppl 59:A186

Shaw AM, Bernetson RA, Phillips MF, Harper PS, Harley HG (1995) Evidence for meiotic drive at the myotonic dystrophy locus. J Med Genet 32:145

Shaw MW, Falls HF, Neel JV (1960) Congenital aniridia. Am J Hum Genet 12:389-415

Shaw RF, Glover RA (1961) Abnormal segregation in hereditary renal disease with deafness. Am J Hum Genet 13:8997

Small KW (1993) Genetic segregation distortion in MCDR1 (North Carolina macular dystrophy). Invest Ophthalmol Vis Sci 34:1305

Stevenson AC, Jennings LM (1960) Ectrodactyly: evidence in favour of a disturbed segregation in offspring of affected males. Ann Hum Genet 24:89-96

Address for correspondence and reprints: Dr. Chris F. Inglehearn, Department of Molecular Genetics, Institute of Ophthalmology, 11-43 Bath Street, London EC1V 9EL, United Kingdom. E-mail: cinglehe@hgmp.mrc.ac.uk (C) 1997 by The American Society of Human Genetics. All rights reserved. 0002-9297/97/6006-0041\$02.00 